\title{
Polycystic Ovary Syndrome, Obesity and Melatonin: An Etiological Perspective
}

\author{
Polikistik Over Sendromu, Obezite ve Melatonin: Etiyolojik Bakış Açısı
}

\section{Büşra Başar Gökcen¹, Makbule Gezmen Karadağ²}

Received/Geliş tarihi: 25.09.2021 • Accepted/Kabul tarihi: 07.12.2021

\begin{abstract}
Although the reproductive and metabolic dysfunctions associated with polycystic ovary syndrome are clearly known, the mechanisms between these dysfunctions are still unclear. One of the hypotheses put forward for these mechanisms is related to circadian rhythm. To date, many reproductive and metabolic dysfunctions have been associated with circadian rhythm disorders. Especially in women with polycystic ovary syndrome, the relationship between melatonin rhythm, which lasts until late in the morning and starts early at night, and metabolic dysfunctions has been revealed by recent studies. When the relationship between obesity and melatonin is examined, it is clearly seen that melatonin exhibits its effect on energy expenditure rather than energy intake. This hormone affects energy expenditure through adipogenesis, thermogenesis, mitochondrial functions and adipocytokines release, and shows anti-obesity effect. It is thought that this review will shed light on further studies on the therapeutic use of melatonin in obesity associated with polycystic ovary syndrome and contribute to the development of strategies for the prevention of obesity.
\end{abstract}

Keywords: Obesity, melatonin, polycystic ovary syndrome, energy balance

\section{ÖZET}

Polikistik over sendromu ile ilişkili üreme ve metabolik disfonksiyonlar net olarak bilinmesine rağmen, bu disfonksiyonların arasındaki mekanizmalar halen net değildir. Bu mekanizmalar için öne sürülen hipotezlerden biri de sirkadiyen ritim ile ilişkilidir. Bugüne kadar birçok üreme ve metabolik disfonksiyon sirkadiyen ritim bozukluğu ile ilişkilendirilmiştir. Özellikle polikistik over sendromlu kadınlarda sabahları geç saatlere kadar süren ve geceleri erken saatlerde başlayan melatonin ritmi ile metabolik disfonksiyonlar arasındaki ilişki son zamanlarda yapılan çalışmalar ile ortaya konulmuştur. Obezite ve melatonin arasındaki ilişki incelendiğinde, melatoninin etkisini enerji alımından ziyade enerji harcaması üzerinden sergilediği net olarak görülmektedir. Bu hormon adipogenezis, termogenezis, mitokondriyal fonksiyonlar ve adipositokin salınımı aracılığıyla enerji harcamasını etkilemekte ve anti-obezite aktivite göstermektedir. Bu derlemenin polikistik over sendromu ile ilişkili obezitede melatoninin terapötik kullanımına yönelik daha ileriki çalışmalara ışık tutacağı ve obezitenin önlenmesine yönelik stratejiler geliştirmede katkıda bulunacağı düşünülmektedir.

Anahtar kelimeler: Obezite, melatonin, polikistik over sendromu, enerji dengesi

1. Correspondence/Illetişim: Muğla Sttkı Koçman University, Fethiye Faculty of Health Sciences, Department of Nutrition and Dietetics, Turkey

Email: busrabasar@mu.edu.tr • @ https://orcid.org/0000-0002-5628-3658
2. Gazi University, Faculty of Health Sciences, Department of Nutrition and Dietetics, Turkey • ๑ https://orcid.org/0000-0003-3202-3250 


\section{INTRODUCTION}

Polycystic Ovary Syndrome (PCOS), one of the main causes of fertility disorders, is the most common metabolic disorder among women of reproductive age. This syndrome is defined as an endocrinopathy characterized by the morphological appearance of polycystic ovaries with anovulatory features (amenorrhea, oligomenorrhea, irregular menstrual cycle) and biochemical and/or clinical manifestations (acne, hirsutism, baldness) of hyperandrogenism (1). In addition to these reproductive dysfunctions present in PCOS, this syndrome is often accompanied by components of the metabolic syndrome such as obesity, atherogenic dyslipidemia, hypertension and insulin resistance. As a result, women with PCOS are at increased risk for some of the main causes of morbidity and early mortality. Therefore, there has recently been increased interest in new therapeutic targets for the prevention and treatment of this adverse health consequences in PCOS (2). The focus of some of these treatment targets is circadian rhythm disorders, which are suggested to be involved in the pathogenesis of the syndrome. In this regard, many studies have been conducted on melatonin, which is well known for its role in the regulation of circadian rhythms of many physiological and neuroendocrine functions (3). Melatonin has anti-oxidant, antiangiogenic, anti-inflammatory, anti-carcinogenic and neuroprotective effects. With these effects, it facilitates the control of chronic diseases such as obesity, diabetes and cardiovascular diseases (4). A recent study has shown that women with PCOS have impaired circadian melatonin rhythm and this is associated with metabolic dysregulations such as obesity (2). The aim of this review is to examine the relationship between melatonin and obesity, which is involved in the pathogenesis of PCOS and accompanies this syndrome, from an etiological point of view.

\section{Melatonin Rhythm and Obesity in PCOS}

It has recently been suggested that obesity, which often accompanies PCOS, may be associated with melatonin rhythm abnormalities, that is, it may be related to the time interval rather than melatonin secretion levels. The duration of melatonin secretion was significantly longer in women with PCOS, which means that melatonin secretion ends later in the morning and begins early at night (2). In an experimental study, it was shown that the difference between day and night melatonin levels was lower in the PCOS group compared to the control group, and the time to reach the peak level of melatonin was delayed (5). Based on these studies, it can be suggested that there is a shift and misalignment in melatonin rhythm in women with PCOS. This may be due to obesity and metabolic dysfunctions that often accompany PCOS. In a recent study, it was shown that melatonin secretion rhythm shifts towards the early morning hours in obese patients, similar to PCOS (6). In addition, the "Timing Model” put forward by Garaulet et al. (7) can also clarify this issue. According to this model, it has been suggested that high levels of melatonin secretion during the biological daytime when food consumption is active may lead to metabolic dysfunctions.

Studies on melatonin and PCOS generally aimed to evaluate the effects of melatonin on the reproductive dysfunctions, and its effect on metabolic functions remained in the background in this population (8). Tagliaferri et al. (9) showed that melatonin supplementation at bedtime for 6 months $(2 \mathrm{mg})$ in women with PCOS alleviated biochemical hyperandrogenism and improved ovulatory dysfunctions, but did not affect metabolic and anthropometric variables. Alizadeh et al. (10) showed that melatonin supplementation at bedtime for 2 months (6 mg) in women with PCOS improves the metabolic profile together with biochemical hyperandrogenism. It has also been shown to reduce waist circumference. In another study, Jamilian et al. (3) showed that $10 \mathrm{mg}$ melatonin supplementation before bedtime for 3 months did not change anthropometric parameters and dietary intakes, but improved hyperandrogenism, inflammation and oxidative stress biomarkers. Genario et al. (11) reported that melatonin supplementation was given at 
doses ranging from 1 to $20 \mathrm{mg} /$ day and the application period varied between 3 weeks and 12 months in studies evaluating the effect of melatonin on obesity. In this review study, significant results on weight loss were not found despite these doses. This makes the proposed role and safety of melatonin in obesity controversial. In conclusion, although the effect of melatonin on reproductive dysfunctions has been clearly demonstrated at almost every supplementation dose, the effects of melatonin on obesity and metabolic profile in PCOS are contradictory.

Melatonin appears to be responsible for the synchronization of numerous physiological effects on the control of obesity and its complications (12). In an experimental study, it was shown that there was a significant increase in body weight in the experimental group exposed to continuous light compared to the control group adopting the light/dark cycle model. It has also been shown in this study that the phenotypic features accompanying continuous light exposure are improved by melatonin supplementation (13). Although it has been demonstrated that abnormalities in melatonin secretion may be involved in the pathogenesis of obesity, a systematic review and metaanalysis on melatonin and body weight has revealed conflicting results. In all clinical trials reviewed in this study, melatonin was used as an adjunct therapy to a pharmacological agent that increases or decreases body weight. As a result, melatonin was hypothesized to have a buffering activity on fluctuations in body weight (14). It has been shown in many experimental studies that melatonin reduces body weight and improves metabolic profile regardless of food consumption. Melatonin exerts its reducing effect on body weight through energy expenditure rather than central feeding behavior mechanisms (energy intake) $(12,15,16)$.

It has been suggested that melatonin, which has been known to have a key role in the regulatory steps of energy metabolism, is involved in each phase of energy balance components such as energy intake, energy storage and energy expenditure. Melatonin increases the volume and activity of brown adipose tissue, and it has been suggested that melatonin is a possible activator of brown adipose tissue. Possible effects of melatonin on brown adipose tissue are attributed to both its central and peripheral activity $(17,18)$. The effects of melatonin on this tissue can be examined under the headings of adipogenesis, thermogenesis, adipocytokines secretion and mitochondrial biogenesis.

\section{Adipogenesis}

Adipogenesis is a well-programmed process consisting of a sequential series of transcription events. In the early phase of this process, two members of the CCAAT/enhancer-binding protein family (C/ EBP $\beta$ and C/EBPS) are activated. These two factors directly activate the expression of two key regulators of terminal adipogenesis, peroxisome proliferator activator receptor gamma (PPAR $\gamma$ ) and C/EBPa (19). Inhibition of the $\mathrm{C} / \mathrm{EBP} \beta$ factor results in decreased early adipogenic transcription and inhibition of the subsequent transcriptional cascade, thereby suppressing terminal adipogenic differentiation. Therefore, it can be considered as a potential target that can prevent or treat obesity. In addition, PPAR $\gamma$, which is involved in the terminal adipogenesis process, regulates glucose and lipid metabolism and the inflammation process. Activation of this factor increases the number of small and insulin-sensitive adipocytes and increases adiponectin levels. With this aspect, it can be thought that PPAR $\gamma$ activation in the terminal phase of the adipogenesis process has a therapeutic potential for obesity (20).

The potential role of melatonin in adipogenesis has been extensively studied in pre-adipose (3T3L1 cell line, intramuscular preadipocytes, etc.) or adipose-derived stem cells (human adipose-derived stem cell and human mesenchymal stem cell, etc.), but conflicting results have been reported. Yang et al. (21) conducted an in vitro study to evaluate the potential effects of melatonin on the proliferation and differentiation of intramuscular preadipocytes. In this study, it was shown that melatonin increased the expression of PPAR $\gamma, \mathrm{C} / \mathrm{EBP} \alpha$ and $\mathrm{C} / \mathrm{EBP} \beta$, thereby 
stimulating the differentiation of preadipocyte into adipocyte containing lipid droplets and high cellular triacylglycerol levels. On the other hand, melatonin has also been shown to activate the lipolysis pathway by upregulating the expression of lipolytic genes and proteins (21). In 3T3-L1 embryo fibroblast preadipocytes, it was shown that melatonin significantly increased the expression of the PPAR- $\gamma$ gene and smaller lipid droplets were formed by overexpressing many molecules associated with lipolysis (22). Melatonin has also been shown to increase gene expression of proteins associated with lipolysis and thermogenesis, such as hormone sensitive lipase (HSL), uncoupling protein 3 (UCP3), lipid droplet associated protein 1 (perilipin, PLIN), adipose triglyceride lipase (ATGL), primarily through the melatonin receptor 2 (MT2) $(21,23)$.

Against the stimulating effects of melatonin on adipogenesis, Alonso-Vale et al. (24) reported for the first time that melatonin acts as a negative regulator of adipogenesis in 3T3-L1 cells. Melatonin has been shown to reduce levels of PPAR $\gamma$ and C/EBPa, the known target of PPAR $\gamma$, as well as late biomarkers of adipocyte differentiation adiponectin and perilipin (24). In a study examining the effects of melatonin on the activities of adipose tissue-derived mesenchymal stem cell, it was shown that melatonin exhibits antiadipogenic activity by reducing the gene expression of the CCAAT/enhancer-binding protein (25).

As a result, melatonin can have both adipogenesis activating and inhibitory action. It can exhibit antiobesity action by improving the metabolic profile and increasing the release of lipolysis-related proteins together with PPAR $\gamma$ when it activates adipogenesis or by reducing the number of mature adipocytes when it inhibits this processes.

\section{Thermogenesis}

Brown adipocytes, specialized to dissipate energy in the form of heat, are known for their important role in adaptive thermogenesis against environmental stimuli such as cold and diet. Shivering thermogenesis is defined as "increased metabolic heat production not associated with muscle activity but associated with metabolic events in brown adipose tissue". Thermogenesis, which is the main determinant of energy expenditure, has an important place in the treatment of obesity (26).

It is well known that melatonin improves resistance to cold and increases the capacity of non-shivering thermogenesis, thus having important roles in thermoregulatory mechanisms (27). It was shown that the adaptive thermogenic capacity of brown adipose tissue was impaired against environmental stimuli such as cold in pinealectomized experimental animals and this situation was reversed with melatonin (28).

Adaptive thermogenesis is dependent on brown adipose tissue-specific uncoupling protein 1 (UCP1) on the mitochondrial membrane. This protein stimulates mitochondrial proton leakage and thus dissipates energy as heat. It has been suggested that melatonin may exert its action on thermogenesis in brown adipose tissue through the UCP1 protein. It has been shown that this protein expression is increased at the mRNA and protein level in preadipocytes treated with melatonin (22). In a study with an experimental model of metabolic syndrome, melatonin supplementation was shown to increase the browning of white adipose tissue in the inguinal region. The increase in browning is explained by the fact that melatonin increases the UCP1 protein expression by two times (29).

Melatonin also carries out its activity on adipose tissue through central pathways. Melatonin primarily exerts its central activity through one of its specific receptors, melatonin receptor 1 (MT1), in the suprachiasmatic nucleus. This melatonin receptor is expressed in the sympathetic nerve exit from the brain to the white adipose tissue. It has been reported that sympathetic activity in white adipose tissue increases due to the stimulation of the receptor in this region (30). Ryu et al. (31) hypothesized that melatonin activation via the MT1 receptor on the central sympathetic nerve outlet to white adipose tissue induces the lipolysis pathway. 


\section{Adipocytokines secretion}

Another effect of melatonin on energy balance is through the release of adipocytokines. In this regard, especially adiponectin, which is one of the adipocytokines, has been focused on. The relationship between adiponectin and melatonin may be based on the downregulation of these hormone receptors by prolonged light exposure. It has recently been shown that adiponectin expression is also controlled by a circadian clock, similar to melatonin (32).

It has been suggested that impaired adipocytokines synthesis and secretion in obesity may be involved in the pathogenesis of obesity comorbidities. In adipocytes hypertrophy, adiponectin secretion decreases, while the secretion of adipocytokines such as resistin and visfatin increases. However, this abnormal adipokine secretion profile is normalized by the binding of melatonin to its specific receptors in adipocytes (33). Despite decreasing adiponectin levels in obesity and diabetes, melatonin upregulates adiponectin levels. Agil et al. (34) showed that decreased adiponectin levels in experimental models of metabolic syndrome increased by $40 \%$ with melatonin supplementation. Although many clinical studies showing that melatonin increases adiponectin gene expression in individuals with metabolic syndrome, further studies are needed (12).

In fact, the relationship between melatonin and adiponectin can also be established through adipogenesis but experimental studies have revealed conflicting results. Melatonin decreases the expression of adiponectin mRNA by $30 \%$ at 36 th hour of differentiation of 3T3-L1 preadipocyte cells (24). In contrast, melatonin has been shown to increase adiponectin secretion and receptor expression in mature adipocyte that have completely completed the differentiation (day 8) (22). This contradiction can be clarified by the knowledge that adiponectin secretion starts at a low level on the 3rd day of adipogenesis and reaches significant levels mainly in the late phase (day 6-7), known as the terminal differentiation period $(35,36)$. In conclusion, it can be hypothesized that melatonin supports optimal maintenance of adiponectin rhythm in adipogenesis. In support of this hypothesis, the reversible effects of melatonin on the impaired 24-hour adiponectin rhythm in obesity have been clearly demonstrated (37).

\section{Mitochondrial functions}

Brown adipose tissue rich in mitochondria is an important site both for melatonin action and synthesis. The antioxidant action of melatonin is necessary for the protection of mitochondria from oxidative stress. Melatonin affects mitochondrial dynamics, supports mitochondrial fusion and inhibits mitochondrial fission, thus increasing ATP production (27). Mitochondrial fusion changes the structure of mitochondria from small to large, and mitochondrial fission changes from large to small. Mitochondrial fusion compensates for mitochondrial damage by binding damaged and healthy mitochondria, while mitochondrial fission helps maintain mitochondrial function by separating damaged mitochondria from healthy areas. Considering this mechanism, the knowledge that factors that inhibit mitochondrial fission and activate fusion increase mitochondrial respiration capacity becomes more plausible (38). On the contrary, the balance between mitochondrial fission and fusion in obesity shifts towards a decrease in fusion-related proteins and an increase in fissionrelated proteins (39). Considering the effect of melatonin on reducing mitochondrial fission and increasing fusion, it can be predicted that it can compensate for this imbalance in obesity.

Mitochondrial biogenesis, a complex biological process, is known as the growth and division of mitochondria. It can be hypothesized that melatonin is protective against obesity through its effects on mitochondrial biogenesis and functions. Kato et al. (22) showed that melatonin promotes mitochondrial biogenesis by increasing citrate synthase activity in 3T3-L1 mouse embryo fibroblast cells. Citrate synthase, an enzyme of the tricarboxylic acid cycle, catalyzes the synthesis of citrate from oxaloacetate and acetyl coenzyme A. This enzyme activity has 
been used as an indicator of mitochondrial content and function in mammals. It has been shown that citrate synthase enzyme activity in mitochondria isolated from adipose tissue in obese individuals is significantly lower (40). As a result, it can be thought that melatonin has an anti-obesity effect by increasing the citrate synthase enzyme activity.

\section{CONCLUSION}

Polycystic ovarian syndrome, which is characterized by many dysfunctions in the reproductive system, is also closely related to many metabolic dysfunctions. While hyperandrogenism, the main characteristic feature of this syndrome, is involved in the pathogenesis of metabolic conditions such as insulin resistance and obesity, it can often accompany these metabolic conditions. This vicious circle has triggered the introduction of many therapeutic agents for the management of metabolic conditions, such as obesity, whose global prevalence is increasing day by day. Melatonin, one of these, has recently attracted attention with its clinical use in the management of PCOS in terms of metabolic dysfunctions and infertility. In PCOS, there are abnormalities in the time intervals in which melatonin is released as well as the levels. Although it has been shown that there is a strong relationship between the complications of PCOS and melatonin, studies are limited in revealing the mechanisms underlying the relationship between obesity and melatonin in PCOS. According to the results of the studies, it has been suggested that melatonin exerts its anti-obesity effect by supporting thermogenesis through its local and central effects on brown adipose tissue, inhibiting adipogenesis in the early period or activating it in the terminal period, improving mitochondrial functions, and normalizing adipocytokines secretion. Although melatonin has been proven at various doses to be effective on reproductive dysfunctions, effective dosage information for obesity and its complications is still unclear. The contradictory results of the studies can be partially explained by the involvement of various factors in the pathogenesis of PCOS and the fact that it is characterized by different phenotypes. Different therapeutic perspectives may be necessary for a hyperandrogenism triggered by obesity and insulin resistance or an insulin resistance triggered by hyperandrogenism. Further studies are needed to clearly reveal this relationship and to generate recommendation-level evidence for the therapeutic use of melatonin.

Author contributions - Yazarlık katkıst: Study design: $B B G, M G K$; Literature review: $B B G$; Draft preparation: $B B G$; Critical review for content: MGK; Final approval of the version to be published: MGK. - Çalışmanin tasarımı: BBG, MGK; İlgili literatürün taranmast: BBG; Makale taslağının oluşturulması: BBG; İçerik için eleştirel gözden geçirme: MGK; Yayinlanacak versiyonun son onayl: MGK.

Conflict of interest - Çıkar çatışması: The authors declare that they have no conflict of interest. - Yazarlar çıkar çatışması olmadığını beyan ederler.

\section{REFERENCES}

1. Moran LJ, Tassone EC, Boyle J, Brennan L, Harrison $\mathrm{CL}$, Hirschberg AL, et al. Evidence summaries and recommendations from the international evidencebased guideline for the assessment and management of polycystic ovary syndrome: Lifestyle management. Obes Rev. 2020;21(10):e13046.

2. Simon SL, McWhirter L, Diniz Behn C, Bubar KM, Kaar JL, Pyle L, et al. Morning circadian misalignment is associated with insulin resistance in girls with obesity and polycystic ovarian syndrome. J Clin Endocrinol Metab. 2019;104(8):3525-34.

3. Jamilian M, Foroozanfard F, Mirhosseini N, Kavossian E, Aghadavod E, Bahmani F, et al. Effects of melatonin supplementation on hormonal, inflammatory, genetic, and oxidative stress parameters in women with polycystic ovary syndrome. Front Endocrinol. 2019;10:18.

4. Meng X, Li Y, Li S, Zhou Y, Gan R-Y, Xu D-P, et al. Dietary sources and bioactivities of melatonin. Nutrients. 2017;9(4):367.

5. Wang F, Xie N, Wu Y, Zhang Q, Zhu Y, Dai M, et al. Association between circadian rhythm disruption and polycystic ovary syndrome. Fertil Steril. 2021;115(3):77181. 
6. Berdina O, Madaeva I, Sholokhov L, Bolshakova S, Rashidova M, Rychkova L. OC17 Evaluation of circadian melatonin secretion in obese adolescents. Arch Dis Child. 2019;104:A7-A8.

7. Garaulet M, Qian J, Florez JC, Arendt J, Saxena R, Scheer FA. Melatonin effects on glucose metabolism: time to unlock the controversy. Trends Endocrinol Metab. 2020;31(3):192-204.

8. Xie F, Zhang J, Zhai M, Liu Y, Hu H, Yu Z, et al. Melatonin ameliorates ovarian dysfunction by regulating autophagy in PCOS via the PI3K-Akt pathway. Reproduction. 2021;162(1):73-82.

9. Tagliaferri V, Romualdi D, Scarinci E, De Cicco S, Di Florio C, Immediata V, et al. Melatonin treatment may be able to restore menstrual cyclicity in women with PCOS: a pilot study. Reprod Sci. 2018;25(2):269-75.

10. Alizadeh M, Karandish M, Jafarabadi MA, Heidari L, Nikbakht R, Rezaei HB, et al. Metabolic and hormonal effects of melatonin and/or magnesium supplementation in women with polycystic ovary syndrome: a randomized, double-blind, placebo-controlled trial. Nutr Metab (Lond). 2021;18(1):57-67.

11. Genario R, Cipolla-Neto J, Bueno AA, Santos HO. Melatonin supplementation in the management of obesity and obesity-associated disorders: A review of physiological mechanisms and clinical applications. Pharmacol Res. 2021;163:105254.

12. de Farias T, Cruz MM, de Sa R, Severi I, Perugini J, Senzacqua $\mathrm{M}$, et al. Melatonin supplementation decreases hypertrophic obesity and inflammation induced by high-fat diet in mice. Front Endocrinol (Lausanne). 2019;10:750-62.

13. Hong F, Pan S, Xu P, Xue T, Wang J, Guo Y, et al. Melatonin orchestrates lipid homeostasis through the hepatointestinal circadian clock and microbiota during constant light exposure. Cells. 2020;9(2):489-510.

14. Mostafavi S-A, Akhondzadeh S, Reza Mohammadi M, Keshtkar A-A, Hosseini S, Reza Eshraghian M, et al. Role of melatonin in body weight: A systematic review and meta-analysis. Curr Pharm Des. 2017;23(23):3445-52.

15. Tung Y-T, Chiang P-C, Chen Y-L, Chien Y-W. Effects of melatonin on lipid metabolism and circulating irisin in sprague-dawley rats with diet-induced obesity. Molecules. 2020;25 (15):3329-40.

16. Ríos-Lugo MJ, Jiménez-Ortega V, Cano-Barquilla P, Mateos PF, Spinedi EJ, Cardinali DP, et al. Melatonin counteracts changes in hypothalamic gene expression of signals regulating feeding behavior in high-fat fed rats. Horm Mol Biol Clin Investig. 2015;21(3):175-83.
17. Amaral FGD, Andrade-Silva J, Kuwabara WM, CipollaNeto J. New insights into the function of melatonin and its role in metabolic disturbances. Expert Rev Endocrinol Metab. 2019;14(4):293-300.

18. Halpern B, Mancini MC, Bueno C, Barcelos IP, de Melo ME, Lima MS, et al. Melatonin Increases brown adipose tissue volume and activity in patients with melatonin deficiency: a proof-of-concept study. Diabetes. 2019;68(5):947-52.

19. Wang QA, Zhang F, Jiang L, Ye R, An Y, Shao M, et al. Peroxisome proliferator-activated receptor $\gamma$ and its role in adipocyte homeostasis and thiazolidinedionemediated insulin sensitization. Mol Cell Biol. 2018;38(10):e00677-17.

20. Jakab J, Miškić B, Mikšić Š, Juranić B, Ćosić V, Schwarz $\mathrm{D}$, et al. Adipogenesis as a potential anti-obesity target: a review of pharmacological treatment and natural products. Diabetes Metab Syndr Obes. 2021;14:67-83.

21. Yang W, Tang K, Wang Y, Zhang Y, Zan L. Melatonin promotes triacylglycerol accumulation via MT2 receptor during differentiation in bovine intramuscular preadipocytes. Sci Rep. 2017;7(1):1-12.

22. Kato H, Tanaka G, Masuda S, Ogasawara J, Sakurai T, Kizaki T, et al. Melatonin promotes adipogenesis and mitochondrial biogenesis in 3T3-L1 preadipocytes. J Pineal Res. 2015;59 (2):267-75.

23. Liu K, Yu W, Wei W, Zhang X, Tian Y, Sherif M, et al. Melatonin reduces intramuscular fat deposition by promoting lipolysis and increasing mitochondrial function. J Lipid Res. 2019;60(4):767-82.

24. Alonso-Vale MI, Peres SB, Vernochet C, Farmer SR, Lima FB. Adipocyte differentiation is inhibited by melatonin through the regulation of C/EBPbeta transcriptional activity. J Pineal Res. 2009;47(3):221-7.

25. Heo JS, Pyo S, Lim JY, Yoon DW, Kim BY, Kim JH, et al. Biological effects of melatonin on human adipose-derived mesenchymal stem cells. Int J Mol Med. 2019;44(6):2234-44.

26. Luginbuehl I, Bissonnette B, Davis PJ. Thermoregulation: Physiology and Perioperative Disturbances. In: Davis PJ, Cladis FP, Motoyama EK, editors. Smith's Anesthesia for Infants and Children (Eighth Edition). Philadelphia: Mosby; 2011. p. 157-78.

27. Mendes C, Gomes G, Belpiede LT, do Carmo Buonfiglio D, Motta-Teixeira LC, Amaral FG, et al. The effects of melatonin daily supplementation to aged rats on the ability to withstand cold, thermoregulation and body weight. Life Sci. 2021;265:118769. 
28. Halpern B, Mancini MC, Mendes C, Machado CML, Prando S, Sapienza MT, et al. Melatonin deficiency decreases brown adipose tissue acute thermogenic capacity of in rats measured by 18 F-FDG PET. Diabetol Metab Syndr. 2020;12:82-8.

29. Jiménez-Aranda A, Fernández-Vázquez G, Campos D, Tassi M, Velasco-Perez L, Tan DX, et al. Melatonin induces browning of inguinal white adipose tissue in Zucker diabetic fatty rats. J Pineal Res. 2013;55(4):41623.

30. Bartness TJ, Shrestha Y, Vaughan C, Schwartz G, Song C. Sensory and sympathetic nervous system control of white adipose tissue lipolysis. Mol Cell Endocrinol. 2010;318(1-2):34-43.

31. Ryu V, Zarebidaki E, Albers HE, Xue B, Bartness TJ. Short photoperiod reverses obesity in Siberian hamsters via sympathetically induced lipolysis and browning in adipose tissue. Physiol Behav. 2018;190:11-20.

32. Barnea M, Chapnik N, Genzer Y, Froy O. The circadian clock machinery controls adiponectin expression. Mol Cell Endocrinol. 2015;399:284-7.

33. Maher AM, Saleh SR, Elguindy NM, Hashem HM, Yacout GA. Exogenous melatonin restrains neuroinflammation in high fat diet induced diabetic rats through attenuating indoleamine 2, 3-dioxygenase 1 expression. Life Sci. 2020;247:117427.
34. Agil A, Rosado I, Ruiz R, Figueroa A, Zen N, FernándezVázquez G. Melatonin improves glucose homeostasis in young Zucker diabetic fatty rats. J Pineal Res. 2012;52(2):203-10.

35. Chang E, Kim CY. Natural products and obesity: a focus on the regulation of mitotic clonal expansion during adipogenesis. Molecules. 2019;24(6):1157.

36. Chen J, Spagnoli A, Torquati A. Omental gene expression of adiponectin correlates with degree of insulin sensitivity before and after gastric bypass surgery. Obes Surg. 2012;22(3): 472-7.

37. Ríos-Lugo MJ, Cano P, Jiménez-Ortega V, FernándezMateos MP, Scacchi PA, Cardinali DP, et al. Melatonin effect on plasma adiponectin, leptin, insulin, glucose, triglycerides and cholesterol in normal and high fat-fed rats. J Pineal Res. 2010;49(4):342-8.

38. Dai W, Jiang L. Dysregulated mitochondrial dynamics and metabolism in obesity, diabetes, and cancer. Front Endocrinol (Lausanne). 2019;10:570.

39. Heo J-W, No M-H, Park D-H, Kang J-H, Seo DY, Han J, et al. Effects of exercise on obesity-induced mitochondrial dysfunction in skeletal muscle. Korean J Physiol Pharmacol. 2017;21(6):567-77.

40. Christe M, Hirzel E, Lindinger A, Kern B, von Flüe M, Peterli R, et al. Obesity affects mitochondrial citrate synthase in human omental adipose tissue. ISRN Obes. 2013;2013:1-8. 